\title{
THE DRAGON AND THE CAPTAIN: CHINA IN THE PERSPECTIVE OF BRAZIL'S NATIONALIST RIGHT
}

Maurício Santoro ${ }^{1}$

Abstract: Since 2009 China has been Brazil's biggest trade partner, and its important ally. However, the nationalist right that won the 2018 elections has a critical perspective of the country. This paper maps the views on China held by the new Brazilian government, both in terms of the economic arguments (protectionism of industry, fear of Chinese control of infrastructure and natural resources) and political concerns (the desire for a diplomatic rapprochement with the United States and anticommunism hostility towards Beijing). The paper claims that these positions are important for foreign policy decision-making and that they complicate relations with China, but that is also necessary to take into account more moderate views from other groups in the administration.

Keywords: Brazil. China. Nationalism. Foreign policy. Right wing.

\section{O DRAGÃO E O CAPITÃO: A CHINA NA PERSPECTIVA DA DIREITA NACIONALISTA DO BRASIL}

Resumo: Desde 2009 a China tem sido o maior parceiro comercial do Brasil e seu aliado importante. Contudo, a direita nacionalista que venceu as eleições de 2018 tem uma perspectiva crítica do país. Este artigo mapeia as visões sobre a China por parte do novo governo brasileiro, tanto em termos do debate econômico (protecionismo industrial, medo do controle chinês da infraestrutura e de recursos naturais) e preocupações políticas (desejo de aproximação com os Estados Unidos e hostilidade anticomunista contra Pequim). $\mathrm{O}$ artigo afirma que essas posições são importantes no processo decisório de política externa e que complicam relações com a China, mas que também é preciso levar em conta visões mais moderadas de outros grupos no governo.

Palavras-chave: Brasil. China. Nacionalismo. Política externa. Direita.

\section{EL DRAGON Y EL CAPITÁN: CHINA EN LA PERSPECTIVA DE LA DERECHA NACIONALISTA DEL BRASIL}

Resumen: Desde el 2009 la China es el más grande socio comercial de Brasil y su aliado importante. Sin embargo, la derecha nacionalista que venció las elecciones de 2018 tiene una perspectiva crítica del país. Este artículo mapea las visiones sobre China por parte del nuevo gobierno brasileño, tanto en términos del debate económico (proteccionismo industrial, miedo del control chino de la infraestructura y de recursos naturales) y preocupaciones políticas (deseo de acercamiento a los Estados Unidos y hostilidad anticomunista en contra Pekín). El artículo afirma que esas posiciones son importantes en el proceso decisorio de política exterior y que

\footnotetext{
${ }^{1}$ Professor-adjunto, Universidade do Estado do Rio de Janeiro, Departamento de Relações Internacionais, Rio de Janeiro, Brasil, mauricio.rocha@uerj.br, https://orcid.org/0000-0002-3339-6991.
} 
complican las relaciones con la China, pero que también es necesario llevar en cuenta visiones más moderadas de otros grupos en el gobierno.

Palavras-clave: Brasil. China. Nacionalismo. Política exterior. Derecha.

\section{Introduction}

The current decade is one of rising nationalist and populist forces against liberalism in Europe and in the Americas. In Brazil the trend has been exacerbated by difficult conditions: the worst economic recession in the modern history of the country and a series of scandals which weakened the major political parties and opened the way to outsiders.

In 2018, Jair Bolsonaro won the presidential election in Brazil. A former Army captain, he ran as the candidate of a small conservative party and his victory highlighted the widespread rejection against the political status quo. His promises concerning diplomacy were to rollback the initiatives of the left wing governments of 2003-2016 and take Brazil closer to the United States. He is the first Brazilian chief of State in 45 years to make public statements criticizing China as a negative influence for the country.

This paper analyses how the Brazilian nationalist right views China, the nation's major economic partner, and the role this political group may play in shaping the foreign policy of president Bolsonaro towards the Asian State. The nationalists are concerned by Chinese companies' increasing influence controlling natural resources and infrastructure in Brazil. The group often expresses a desire of a closer relationship with Western countries, sometimes because of cultural and religious reasons.

The first section seeks to explain the context of the rise of the nationalist right in Brazil, and how it managed to leave its marginal position in the country's political landscape since the return of democracy to become again a major force, able to win elections. This change is exemplified by the changes in the career's fortune of Bolsonaro, who was for most of his career a backbencher in Congress, without any meaningful responsibilities.

After that, the paper analyses the views on China by the nationalist right, divided in three major lines of thinking: economic policy, national security and cultural identity. This article highlight that the conservative nationalists are divided in two contending groups: the senior military officers, more moderate and closer to the 
traditions of Brazilian diplomacy, and the anti-globalist faction, with similar agendas to the populist movements in the United States and Europe.

The third and final section addresses how the nationalist right influences the decision-making process of Brazil's foreign policy toward China under Bolsonaro, stressing that its ideological aims have been undermining by its internal divisions and by the economic pressures of interest groups linked to Chinese trade and investments.

\section{The rise of the nationalist right in contemporary Brazil}

Brazil made its transition to democracy in 1985, after a 21 -year military dictatorship. The authoritarian regime was fiercely anti-communist, but it did not follow blindly the American leadership in the Cold War. Especially during the economic booms of the 1970s, Brazilian generals pursued an autonomous foreign policy that aimed at increasing ties with other developing countries in Africa and the Middle East. The military also opposed the non-proliferation international regime and developed a nuclear program which was often at odds with Western attempts to control the spread of atomic technology. (Vizentini, 1998; Bueno and Cervo, 2003).

In the first decades of the new democracy, the nationalist right was in a difficult political moment, weakened by its association with the dictatorship and by the effort of conservative parties to reinvent themselves as the defenders of a liberal economic agenda, supporting reforms such as lowering tariffs, promoting privatization and inserting Brazil in a more open and integrated global economy. (Mainwaring, Meneguello and Power, 2000).

In the 1990s Brazil joined several international regimes forbidding weapons of mass destruction (biological, chemical, nuclear) and protecting human rights - the opposite of the policies of the authoritarian regime. Right-wing nationalist politicians were relegated to the fringe of the public debate, often seemed as outdated or even comical figures whose time has passed.

This scenario started to change after the global financial crisis of 2008 and after Brazil plummeted into deep economic and political turbulence in the following decade. Widespread corruption scandals affected the major parties, the country faced a severe recession with over $8 \%$ of GDP loss and record unemployment levels of $12 \%$.

The nationalist right started to rise again with an anti-left rhetoric that blamed Brazil's progressives presidents for the crisis, and playing the nostalgia card for the 
dictatorship, when growth rates were high. This economic agenda went together with a conservative movement critical of ethnical and sexual minorities, feminist groups, artists and intellectuals. On the whole, there were many similarities with the Donald Trump in the United States and the populist parties in Europe. These points in common were noted both by observers and by the Brazilian nationalist politicians and his supporters, who highlighted their shared values (Sedgwick, 2019).

The most important leader of the new nationalist right in Brazil is Jair Bolsonaro. A military court retired him from the Armed Forces in the early 1990s, with the rank of captain, after he made illegal demonstrations in support of a pay rise for the troops. Then he launched a political career and spent the next three decades as a Congressman. Although Bolsonaro was always reelected, he never managed to approve any meaningful bill, and was basically a backbencher acting as a trade union leader for low-ranking soldiers and police officers.

Bolsonaro's fortunes changed with the crisis of the current decade and he rose in popularity as a symbol of anger and discontentment with the problems of the Brazilian political system. He presented himself as an outsider who was never trusted by the country's political establishment and who would fight against corruption and make Brazil great again. He surprised most observers by winning the presidential election of 2018 without the support of major political parties and with almost no TV time, using mostly social media to spread his slogans and to mobilize his supporters. (Winter, 2018).

\section{The Place of China in Brazil's nationalist right worldview}

Bolsonaro's campaign manifesto was a document written in bullets points and small sentences in the manner of a power point presentation. It had just one page dedicated to foreign policy, where the candidate promised to build strong ties with the United States, Israel and Italy, and to distance Brazil from left-wing governments in Latin America. (Bolsonaro, 2018). These vague statements left many analysts and foreign diplomats confused, wondering what would be the new president's diplomacy.

However, Bolsonaro had already made many statements about China, in which he criticized its government in harsh ways. He became the first Brazilian president in 45 years to voice this kind of criticism about a country which has been increasingly important to Brazil. China is the top national trading partner since 2009, 
with a bilateral foreign trade of US $\$ 100$ billion in 2019 . Around $25 \%$ of Brazilian exports are sold to Chinese markets, concentrated on soy, iron ore and oil. China has US $\$ 70$ billion invested in Brazil, especially on energy, agriculture and mining. ${ }^{2}$

During the campaign, Bolsonaro also broke Brazilian diplomatic tradition visiting Taiwan - something that no other leader of Brazil ever did. The trip was part of an Asian tour that included Japan and South Korea and ostensibly left out the People's Republic of China. In Taipei, he praised Taiwanese society as a synthesis of the best of American and Japanese culture. Chinese diplomats in Brazil feared that it was a sign of ending the "One China policy" that all Brazilian administrations followed since 1974, and reacted sending a letter to all members of Brazil's Congress highlighting how important this issue is to Beijing. (Santoro, 2018).

The anti-China statements were not limited to the president. He chose as his minister of Foreign Affairs career diplomat Ernesto Araújo, a newly promoted ambassador who had written magazine articles and blog posts in support of Trump's vision of international affairs and who argued for need of Western countries to reconnect with their Christian heritage in order to face what he saw as the threat of a rising China. (Araújo, 2017; Dieguez, 2019; Lapper, 2019). These positions are rare in Brazil's foreign service, whose members are usually quite open to stronger ties with Beijing and helped to build partnerships such as the BRICS, BASIC, G20 and other multilateral groups that put Brazil and China together.

The president and the minister are not the only ones who speak on behalf of the nationalist right in Brazil. Several groups also defended these ideas and became an important part of the public debate about foreign policy in Brazil. They usually describe themselves as "anti-globalists", taking the term from the new American right to state that they do not oppose globalization per se, but what they believe is a liberal plot to weaken nation states and national culture to promote left wing values.

Among the members of this group in Brazil is one of the president's son, congressman Eduardo Bolsonaro, and the special international advisor to the president, Filipe Martins. Their most important intellectual reference is Olavo de Carvalho, a writer influential on social media and who became a symbol for conservative movements in Brazil due to his harsh opposition to the left. In many ways he is a bridge between the new right in the United States (where he has been living for many years), Europe and its Brazilian counterparts. Carvalho is considered

\footnotetext{
${ }^{2}$ http://www.mdic.gov.br/index.php/comercio-exterior/estatisticas-de-comercio-exterior. Access in April 2020.
} 
to be the most important ideological mentor of Bolsonaro and was key in the nomination of the ministers of Foreign Affairs and Education.

The Armed Forces are important in the Bolsonaro administration. Generals, Admirals and Air Force senior officers form more than one third of the cabinet and are also present as chairmen of public companies and state agencies. They represent a more moderate trend of the nationalist right.

They have a conservative view of foreign policy, which usually supports the consensus of the last decades but are more critical of the rapprochements with Latin American left-wing regimes, of international human rights NGOs and usually careful about China. Many of the Army generals, including the vice-president and several ministers, served in UN peacekeeping missions in Haiti and Africa, and respect multilateral institutions, recognizing their importance to Brazil. In economic affairs, the current leadership of the Armed Forces is more open to free trade and globalization than at the time of the military regime. (Santoro, 2019b).

The criticism of China by the nationalistic right in Brazil may be classified in three major lines of argumentation: economic policy, national security and cultural identity. The first one is shared by many other groups, the latter two are peculiar of this political line of thinking.

The criticism centered on economic policy blames China for unfair competition against Brazilian industry and points to Chinese practices such as dumping, low salaries or weak labor/environmental legislation as factors that curb Brazilian industrial development. These discussions are not exclusive to Brazil, but they have special resonance in a country that faced a severe backslash in terms of deindustrialization, with sectors like textiles and toys suffering the negative impacts of China's imports.

Bolsonaro's own views on international trade are ambivalent. In his career in Congress he has sided with protectionist groups who were against a bigger opening of the Brazilian economy. However, in his presidential campaign he assumed promarket and free trade positions which are defended by the country's business establishment, and nominated an economic team aligned with this worldview. That puts Bolsonaro in sharp contrast with other nationalist politicians in the United States and Europe, who are usually in favor of higher tariffs and less globalization.

National Security is a more common option for the nationalist right in its criticism of China. This is usually expressed as a concern about Chinese control of natural resources and infrastructure in the country. The most famous statement from 
Bolsonaro on the issue is his line that: "China is not buying in Brazil. China is buying Brazil." 3

The president is not alone in this view, which is shared by many officers in the Armed Forces. They do not like the idea of having a foreign dictatorship in charge of key assets in Brazil. Chinese investment just started to being meaningful in the 2010s, concentrated in agriculture, energy and mining.

The last line of criticism is the one that is more specific of the nationalist right: Cultural Identity. This is the case - dear for Bolsonaro and ambassador Araújo - that Brazil should seek a special relationship with the United States and closer ties to the Western nations. It often has a religious approach, emphasizing the Brazilian Christian heritage and highlighting that China has very different values and political system:

Foreign Minister Ernesto Araújo has been has been perhaps the most strident antiChina voice. A career foreign service officer who worked for several years in Washington, Araújo has said he opposes the Paris climate deal because such "dogma" favors China. "We want to sell soy and iron ore, but we're not going to sell our soul," he told an audience of diplomats in March. Eduardo Bolsonaro, a member of Congress and the most influential of the president's three sons on foreign policy issues, has taken an even tougher line, saying Brazil drew close to China for "ideological reasons," much like a previous Brazilian president did with Adolf Hitler's Germany in the 1930s. (Lapper, 2019)

Statements like these contradict the traditional pillars of Brazilian foreign policy, such as support for multilateralism, and a pragmatic approach regarding to international trade. For example, it was the dictatorship that recognized the PRC in 1974. Despite the anti-communism of the military regime, the decision was motivated by economic opportunities, and it was following the Washington-Beijing rapprochement of the 1970's. (Spektor, 2010).

How influent is the nationalist right in the decision-making process of Brazilian foreign policy towards China? Do their opinions carry weight? Or they are just a rhetorical tool for the president, without any real political power?

\section{The nationalist right in Bolsonaro's foreign policy}

The foreign policy of Bolsonaro will be the result of conflicts between several groups that are part of the government. The nationalist right is divided in two contending factions: the anti-globalists and the military officers. And there also the

\footnotetext{
${ }^{3}$ https://videos.bol.uol.com.br/video/a-china-esta-comprando-o-brasil-diz-o-presidenciavel-jair-bolsonaro0402CD9A3460D0996326. Access in April 2020.
} 
technocrats in the ministries of Foreign Affairs, Economy and Agriculture. The relationship with China is one the major disagreements between them.

The anti-globalist positions break the foreign policy consensus about China that has been guiding Brazil's relations with Beijing since 1974. In general lines, the diplomatic approach of Brazilian presidents towards the Chinese is that they are important partners, with many similar interests in global forums. China is perceived as a key player in international affairs, and that Brasília should engage with Beijing to diversify its options regarding traditional allies in the Americas and Western Europe. From the 1990s, it has been also a big economic market for Brazil's exports. (Oliveira, 2004).

Anti-globalists are usually young and somewhat of outsiders - ambassador Araújo, for example, was until a few months ago a middle-rank diplomat, who was never the head of a foreign mission or held high office in the ministry of Foreign Affairs. They usually have a strong social media presence, but tend to be mocked by the traditional press outlets, who often present them as radicals.

The main adversary of the anti-globalists in the administration have been the senior military officers in the ministerial cabinet and state agencies. The conflict led to disagreements and offences exchanged through the media and to the firing of many officials, including cabinet ministers, aligned with both groups.

The vice-president Hamilton Mourão, a retired Army general, rose as the key player for the Brazilian groups searching for a pragmatic relationship with China. Mourão stressed the importance of the Chinese market and investments for Brazil, and that Brasília should not take sides in the trade war between Washington and Beijing, and instead try to use the conflict as an opportunity to boost the country's national interests.

The vice-president stated that the government will not veto Huawei business in Brazil and that the Chinese company will be able to take part in the auction to implement the $5 \mathrm{G}$ Internet pattern. He also expressed caution about the possibility on Brazil joining the New Silk Road, but highlighting that China's investments are welcomed. (Santoro, 2019a).

Other important groups are the economic technocrats. Minister of Economy Paulo Guedes is spearheading an ambitious reform of the Brazilian State with the goal of making the economy more open and with less bureaucracy. That put him in conflict with the nationalist right, because their religious and nationalist views often create trouble with Brazil's trade partners, such as China and the Arab League. The 
economic officials usually see Chinese investments as a key opportunity for the Brazilian public-private partnership program, aimed at overcoming the infrastructure bottleneck.

Concerning the Sino-Brazilian agenda, the technocrats and the military officers have been allies against the anti-globalist faction. They evaluate China in terms of economic opportunities and costs, and reject perspectives related to cultural identity or to religious background. Their position follows the consensus of Brazilian foreign policy elite, despite the political changes of the 2018 election.

In other words, foreign policy will be the object of a strong dispute among these several groups. The anti-globalists will get lot of headlines because of their controversial statements. During the first year of his administration (2019), Bolsonaro usually conducted a pragmatic diplomacy towards China, including a successful visit to the country. Chinese investment from state owned companies was politically important in the November 2019 pre-salt oil auction - if not for their apport, only the Brazilian Petrobras would have taken part in the operation. 4

However, the anti-China trend is still present in the sidelines of the administration and it sometimes comes to the center of the debate. During the Covid19 pandemic, people close to the president - such as his son Eduardo Bolsonaro and the minister of Education, Abraham Weintraub - blamed Beijing for the outbreak of what they called "the Chinese virus". These comments provoked strong responses from China's diplomats in Brazil, who have become very active on social networks and mainstream media ${ }^{5}$.

The tensions did not escalate into a major change of foreign policy, but they raised the mistrust in Brasilia-Beijing relations in the middle of the delicate situation of the pandemic, and stimulated state governors to pursue their own medical diplomacy with China, in search of masks and respirators. ${ }^{6}$ Episodes that exemplify the new elements of instability that are now part of the Sino-Brazilian bilateral agenda.

\footnotetext{
4 “As estatais chinesas que chamaram a atenção no leilão do pré-sal”, Época, 11/06/2019. https://epoca.globo.com/economia/as-estatais-chinesas-que-chamaram-atencao-no-leilao-do-pre-sal-24066343. Access in April 2020.

5 "O influenciador digital de Pequim na polarização", $O$ Estado de São Paulo, 04/11/2020. https://politica.estadao.com.br/noticias/geral,o-influenciador-digital-de-pequim-na-polarizacao,70003268057. Access in April 2020.

6 "A diplomacia paralela da compra de respiradores pelo Maranhão", Nexo Jornal, 04/21/2020. https://www.nexojornal.com.br/expresso/2020/04/21/A-diplomacia-paralela-da-compra-de-respiradores-peloMaranh\%C3\%A3o. Access in April 2020.
} 


\section{Final Considerations}

The nationalist right returned to power in Brazil in the wave of the crisis of the 2010s after a hiatus of more than 30 years. In the new democracy it was traditionally associated with the military dictatorship and perceived as outdated in face of conservative parties who were trying to adapt themselves to a new context of globalization.

The corruption scandals, economic recession and political instability of the current decade discredited Brazilian main parties and opened the way to outsiders and backbenchers, and led to the victory of Bolsonaro in the 2018 elections. The president shares many of the values and worldview of the nationalist right in foreign policy, such as the priority of the relations with the United States and a critical view of China.

These criticisms are basically divided along three lines: economy policy, pointing to how Brazilian industry loses from unfair competition from China; national security, highlighting concerns about Chinese control of key natural resources and infrastructure; and cultural identity, stressing Brazil's ties with the Western nations and the need to seek out a Christian heritage in diplomacy.

The nationalist right is divided in two contending groups. One, more moderate and closer to traditional conservatives, is the senior military officers in the Bolsonaro administration. The other is the anti-globalist faction, which has many similar points with the new conservative and populist movements in the United States and Europe. It breaks the consensus of the foreign policy elites and clashes with several organized interests who benefit from Chinese trade and investments.

The new nationalist right rise is important to Brazilian diplomacy. It does not set the agenda, but it influences the relationship with China, sometimes creating frictions. A pragmatic approach, more open to economic partnership with Beijing, has been in course, based upon an alliance between the military officers and technocrats. In practice many of their criticism of the Chinese have been sidelined in face of the difficult economic situation of Brazil and it will probably be so in the near postpandemic future, when Asia's markets will be even more important for Brazilian products.

\section{References}


ARAÚJO, E. Trump e o Ocidente. Cadernos de Política Exterior. Ano III. Número 6. 2ํㅡㄴ semestre 2017.

BUENO, C. and CERVO, A. História da Política Exterior do Brasil. Brasília: Editora da Unb, 2003.

BOLSONARO, J. O Caminho da Prosperidade: proposta de plano de governo. Available athttp://divulgacandcontas.tse.jus.br/candidaturas/oficial/2018/BR/BR/2022802018/28000061 4517/proposta 1534284632231.pdf. 2018.

DIEGUEZ, C.O Chanceler do Regresso. Revista Piauí, abril de 2019.

LAPPER, R. Bolsonaro took aim at China. Then reality struck. Americas Quarterly, 2019. Volume 13, Issue 2.

MAINWARING, S., MENEGUELLO, R. and POWER, T. Partidos Conservadores no Brasil Contemporâneo. São Paulo: Editora Paz e Terra, 2000.

OLIVEIRA, H. Brasil-China: trinta anos de uma parceria estratégica. Revista Brasileira de Política Internacional, Volume 47, Issue 1, 2004.

SANTORO, M. Bolsonaros' troubled relationship with China. Diálogo Chino, 03/26/2020. Available at: https://dialogochino.net/en/trade-investment/the-bolsonaros-relationship-with-chinacoronavirus/

SANTORO, M. Mourão ganha protagonismo com viagem à China. Revista Época, 05/26/2019a. Available at: https://epoca.globo.com/mourao-ganhou-protagonismo-em-viagemchina-artigo-23694767

SANTORO, M. Bolsonaro's Diplomacy: three groups clash for foreign policy control. Brazilian Report, 01/04/2019b. Available at: https://brazilian.report/opinion/2019/01/04/bolsonaro-diplomacy-foreign-policy/

SANTORO, M. A Gafe de Bolsonaro. O Globo, 03/14/2018, A3.

SEDGWICK, M. Key Thinkers of the Radical Right. Oxford: Oxford University Press, 2019. SPEKTOR, M. Azeredo da Silveira: um depoimento. Rio de Janeiro: Editora da Fundação Getúlio Vargas, 2010.

VIZENTINI, P. A Política Externa do Regime Militar Brasileiro. Porto Alegre: Editora da UFRGS, 1998.

WINTER, Brian. System Profile: behind the rise of Jair Bolsonaro. Americas Quarterly, 2018. Volume 11, Issue 1.

\section{NOTAS DE AUTOR}

\section{CONTRIBUIÇÃO DE AUTORIA}

Maurício Santoro - Concepção. Coleta de dados, Análise de dados, Elaboração do manuscrito, revisão e aprovação da versão final do trabalho

\section{FINANCIAMENTO}

Não se aplica.

CONSENTIMENTO DE USO DE IMAGEM

Não se aplica.

APROVAÇÃO DE COMITÊ DE ÉTICA EM PESQUISA

Não se aplica. 


\section{LICENCCA DE USO}

Este artigo está licenciado sob a Licença Creative Commons CC-BY. Com essa licença você pode compartilhar, adaptar, criar para qualquer fim, desde que atribua a autoria da obra.

\section{HISTORICO}

Recebido em: 20-05-2020

Aprovado em: $18-08-2020$ 